\title{
Design and Fabrication of High Gradient Accelerating Structure Prototype at $36.5 \mathbf{G H z}^{*}$
}

\author{
V. A. Dvornikov and I. A. Kuzmin \\ Small Accelerator Laboratory Moscow Engineering Physics Institute \\ Kashirskoe Shosse, 31, Moscow, 115409 Russia
}

\section{Abstract}

Disc loaded waveguide (DLWG) at $36.5 \mathrm{GHz}$ was chosen as prototype of accelerating structure for reaching gradient up to $100 \mathrm{MV} / \mathrm{m}$. The results of calculation and fabrication of DLWG cells are given. The technique of matching DLWG to input and output couplers is described.

\section{INTRODUCTION}

This paper describes results of design and fabrication of accelerating structure to reach the gradient up to $100 \mathrm{MV} / \mathrm{m}$ at $36,5 \mathrm{GHz}$. We used the results of the investigations, carried out at CLIC [1], to choose DLWG as accelerating structure.

\section{DESIGN AND FABRICATION DLWG CELLS}

DLWG cell is shown in Fig.1. The calculations were carried out by PRUD-0 [2]. The results of calculations are presented in Table 1.

Table 1

Structure parameters at $36.5 \mathrm{GHz}$

\begin{tabular}{l|c}
\hline \multicolumn{1}{c|}{ Parameters } & Value \\
\hline Phase velocity $\beta_{\mathrm{ph}}$ & 1 \\
Quality factor $Q$ & 4140 \\
Shunt impedance $r, \mathrm{M} \Omega / \mathrm{m}$ & 120 \\
Group velocity $b_{\mathrm{g}}$ & 0.074 \\
Section length $l, \mathrm{~mm}$ & 164.1 \\
Cells per section $N$ & 60 \\
Iris aperture over wavelength $\alpha / \lambda$ & 0.2 \\
Travelling wave mode & $2 \pi / 3$ \\
\hline
\end{tabular}

The level of tolerances, required on main cell dimensions in order not to exceed the frequency error $\pm 5 \mathrm{MHz}$ must be $\pm 0.001 \mathrm{~mm}$. Theoretical estimates show that for copper at $36.5 \mathrm{GHz}$ a surface finish of $R_{\mathrm{a}} \leq 0.04 \mu \mathrm{m}$ is required to a obtain $90 \%$ of the theoretical $Q$ value. The copper cells were machined to required tolerances and surface finish $R_{\mathrm{a}} \leq 0.160 \mu \mathrm{m}$ on precision diamond tool lathe with using special developed technology. After fabrication the frequency of each cell was measured by resonance method. The five cells of seventy five cells were incorrect. After this, the frequencies of resonance stacks of three, six, nine, twelve cells were measured. The dispersion curve is shown in Fig. 2.

\footnotetext{
* Work was supported by JINR, Dubna, Russia
}

\section{MATCHING OF COUPLERS TO DLWG STRUCTURE}

The problems of matching couplers to DLWG structure with large cell-to-cell coupling are described in [3]. The main difficulty is to get first matched coupler. We choose the coupler of SLAC-type with off-axis iris of coupling and off-axis cutoff frequency hole for vacuum pumping (Fig.3).

The matching was made in several stages.

1 . The coupler with variable dimension $2 b$ was developed.

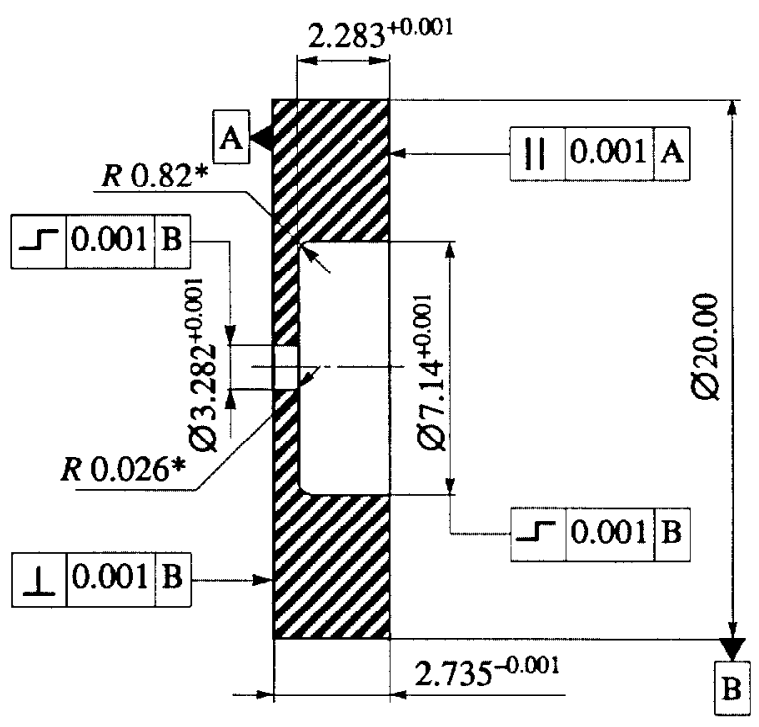

Figure 1. DLWG cell.

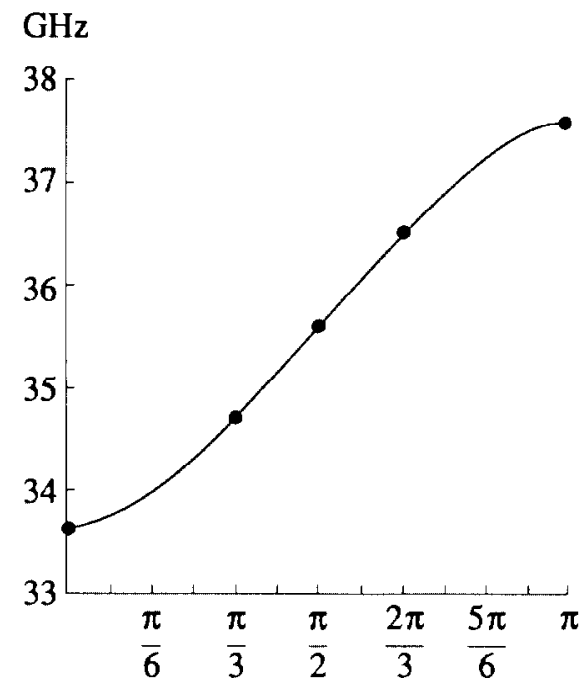

Figure 2. Dispersion curve. 

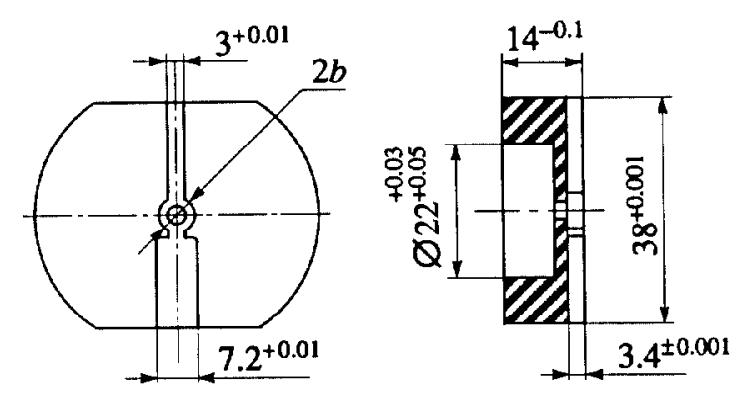

Figure 3. Coupler for DLWG.

2. Two "variable" couplers were matched to twelve cells of DLWG by increasing iris of coupling with rectangular waveguide $(7.2 \times 3.4 \mathrm{~mm})$ until VSWR of input coupler $\leq 1.02$.

3. Two working couplers were matched successively as input couplers, when the "variable" matched coupler was connected to output. The procedure of determination VSWR of input coupler was to remove cells (each cell removed changes phase by $2 \pi / 3$ and 3 impedance points are sufficient to cover $2 \pi$ ) and to measure VSWR [3].
Sixty cells of DLWG were assembled in vacuum tube with two working matched couplers and preliminary vacuum pumping was made.

\section{CONCLUSION}

DLWG for operation in the $2 \pi / 3$ mode at $36.5 \mathrm{GHz}$ was made. VSWR of input coupler at operating frequency was 1.02 . Calculations show, that accelerating gradient will be $100 \mathrm{MeV} / \mathrm{m}$ at input power about $41 \mathrm{MW}$.

\section{REFERENCES}

[1] I. Wilson, W. Schnell, and H. Henke, "Design and Fabrication Studies of High Gradient Accelerating Structures for CERN Linear Collider (CLIC)," CERN/LEP - RF/88-50 and CLIC Note 76, October 1988.

[2] A.G. Daikovskii, I.I. Portugalov, and A.D. Riabov, Part. Accel., 12(1982), p.59.

[3] I. Wilson, "Status of Structure Studies (CLIC)," The 2-nd International Workshop on Next-Generation Linear Collider. 